\title{
PTPRK Gene
}

National Cancer Institute

\section{Source}

National Cancer Institute. PTPRK Gene. NCI Thesaurus. Code C106113.

This gene is involved in receptor signaling, cell-cell contact and cell migration. 